\title{
Analysis of deep-ocean volcanic activity using hydroacoustic techniques
}

\author{
${ }^{1}$ Robert P. Dziak \\ 1-Pacific Marine Environmental Laboratory - National Oceanic and Atmospheric Administration - NOAA - USA \\ gsampaiodemelo@ucsd.edu
}

Copyright 2021, SBGf - Sociedade Brasileira de Geofísica.

This paper was prepared for presentation during the $17^{\text {th }}$ International Congress of the Brazilian Geophysical Society held in Rio de Janeiro, Brazil, 8 -11 November 2021 (Online Event). This paper was prepared for presentation during the $17^{\text {th }}$ International Congress of the Brazilian Geophysical Society held in Rio de Janeiro, Brazil, 8 -11 November 2021 (Online Event).
Contents of this paper were reviewed by the Technical Committee of the $17^{\text {th }}$ International Congress of the Brazilian Geophysical Society and do not necessarily represent any position of the SBGf, its officers or members. Electronic reproduction or storage of any part of this paper for commercial purposes without the written consent of the Brazilian Geophysical Society is prohibited.

In 1995, NOAA-PMEL built and deployed one of the world's first deep-ocean hydrophones that was capable of recording continuous, low-frequency $(10 \mathrm{~Hz}-1 \mathrm{kHz})$, broadband ambient oceanacoustic data for 2-3 years. We have used our novel deep-sea passive acoustic sensor to detect and study a wide range of marine geophysical and biological phenomena throughout the world's oceans. Hydroacoustic signals propagating through the water-column can often be detected at much greater distances than seismic waves propgating through the solid Earth. In this talk, I will present an overview of our research on the use of hydroacoustic techniques to quantify deep ocean earthquake and volcanic activity. Highlights include 1) the detection of magma intrusion and seafloor eruption at Axial Seamount (northeast Pacific ocean), 2) explosion records of the deepest volcanic eruption directly observed (West Mata volcano, western equatorial Pacific), and 3) the 2017 shallow water eruption of Bogoslof volcano in the Aleutian Islands. 